\title{
Morphology, Mechanical and Thermal Properties of Thermoplastic Polyurethane Containing Reduced Graphene Oxide and Graphene Nanoplatelets
}

\author{
Michał Strankowski ${ }^{1, *}$ (1) , Piotr Korzeniewski ${ }^{1}$, Justyna Strankowska ${ }^{2}$, Anu A. S. ${ }^{3}$ and \\ Sabu Thomas ${ }^{3}$ \\ 1 Gdansk University of Technology, Chemical Faculty, Polymer Technology Department, Narutowicza 11/12, \\ 80-233 Gdansk, Poland; piotr.korzeniewski90@gmail.com \\ 2 Institute of Experimental Physics, Faculty of Mathematics, Physics and Informatics, University of Gdansk, \\ Wita Stwosza 57, 80-308 Gdansk, Poland; fizjkr@ug.edu.pl \\ 3 International and Inter University Centre for Nanoscience and Nanotechnology, Mahatma Gandhi \\ University, Kottayam, Kerala 686560, India; anumgu@gmail.com (A.A.S.); sabuthomas@mgu.ac.in (S.T.) \\ * Correspondence: micstran@pg.gda.pl; Tel.: +48-58-347-2434
}

Received: 17 November 2017; Accepted: 4 January 2018; Published: 6 January 2018

\begin{abstract}
Polyurethane/graphene nanocomposites were synthesized using commercial thermoplastic polyurethane (TPU, Apilon 52DE55), and two types of graphene derivatives: graphene nanoplatelets (GNP) and reduced graphene oxide (RGO). Fourier Transformation Infrared Spectroscopy Fourier Transformation Infrared Spectroscopy (FTIR) spectroscopy, TEM, and SEM microscopy and XRD techniques were used to chemically and structurally characterize GNP and RGO nanofillers. The properties of the new TPU nanocomposite materials were studied using thermal analysis techniques (Dynamical Mechanical Analysis (DMA), Differential Scanning Calorimetry (DSC), Thermogravimetric Analysis (TG)) to describe the influence of graphene nanofillers on polyurethane matrix. Our investigation describes the comparison of two types of graphene derivatives, commercial one (GNP) and synthesized (RGO) on thermoplastic polyurethanes. These nanofillers provides opportunities to achieve compatibility with the TPU matrix. The property enhancements are attributed commonly to high aspect ratio of graphene nanoplatelets and filler-polymer interactions at the interface. The obtained nanocomposites exhibit higher thermal and mechanical properties due to the good dispersion of both nanofillers into TPU matrix. It was found that the addition of 2 wt \% of the nanofiller could lead to a significant reinforcement effect on the TPU matrix. Also, with high content of nanofiller (GNP and RGO), the Payne effect was observed.
\end{abstract}

Keywords: polyurethane; nanocomposites; graphene; thermal analysis; mechanical properties

\section{Introduction}

Since the first scientific on the mechanical exfoliation of graphite into graphene monolayers by scotch-tape, several interesting studies have been published on graphene [1-3]. Graphene has become very popular research material during the last few years [2]. This method (scotch-tape approach) of obtaining graphene is inefficient for large-scale production [4]; therefore, many efforts have been undertaken to find a better way to get graphene monolayers. Promising large-scale methods of graphene fabricate are bottom-up methods (especially epitaxially growth on SiC crystal, chemical vapour deposition (CVD)), top-down methods, such as chemical, electrochemical, plasma-assisted, and mechanical exfoliation [5]. These methods mainly differ in the quality and efficiency of the obtained graphenes.

Bottom-up methods allow for the production of wafer graphene, which covers the demand of the electronic industry. The high quality of graphene monolayer shows the high electrical conductivity 
and transparency of this material. Quality of graphene produced by bottom-up approach shows well-builded one-layer structure without atomic defects [6]. The method of manufacturing this type of graphene was developed and patented by Institute of Electronic Materials Technology in Warsaw, Poland [7], and it is process of implementing at the industry scale. The main applications of these graphenes are focused to apply in displays, solar cells [8], integrated circuits elements (transistors [9]), and many other electronic devices.

Top-down approach of obtaining graphene is based on graphite as a raw material. In this way, graphite is exfoliated as the result of breaking inter-plane $\pi-\pi$ interactions of stacked graphene in graphite crystal. Exfoliation can be carried in a mechanical, chemical, electrochemical, and plasma assisted way. According to top-down production methods, the obtained graphenes can differ in chemical and physical properties. The main differences are in crystal defects, various multi-layer stacked structure, polydispersity of basal plane, and thickness. The monolayer structure of top-down graphene can be folded and sharp-edged. We can also add function groups by various chemical modifications. These modifications have a strong effect on the electrical, mechanical, and optical properties of graphene obtained by top-down ways.

Top-down graphene is promising nanofiller for segmented polyurethane matrix. It can be introduced to matrix via in-situ polymerization, solvent-methods and during extrusion [10-12], or injection molding [8]. The addition of graphene allows for meeting the increasing requirements put in many applications. Besides the improvement of mechanical properties [10-26] and thermal stability $[10,16,27,28]$, the modification of segmented polyurethanes by graphene can improve shape memory effect [15,21,24,25,29-31], gas-barrier properties [19], and electrical conductivity [16,18,19,23,32]. Graphene-polyurethane nanocomposites can be used as a selective membrane in filtration [33], piezoelectric sensors [34,35], actuators [30,36], or self-healing materials [20,37,38].

Elastomeric materials can be successfully modified with many nanofillers [39], especially clays, CNT [40], or graphene derivatives [41,42]. These different nano-modificators could cause high improvement in the properties (at low addition, up to 5\%) of the polyurethane (PU) matrix because of the interactions between polyurethane chains and fillers at the nano-scale levels. Also, specific geometry (one-dimensional (1D), two-dimensional (2D), and three-dimensional (3D)) of these nanofillers [43] influence on the mechanical [44], thermal [44], or barrier properties [19] of polyurethane nanocomposites. Simply unmodified nanofillers have limited use, because of the compatibility issues of the polyurethane chains of hard and soft segments with the nano scale fillers. Therefore, the useful list of nanofillers include some "defected" form of graphene, modified CNT, and organically modified clays. The most important improvement of polyurethane matrix was achieved by using OMMT, CNT, or graphene derivatives, which are widely investigated and presented into Table 1.

Table 1. Comparison of the improvements by the nanofilles on the polyurethane matrices.

\begin{tabular}{|c|c|c|c|c|c|c|}
\hline $\begin{array}{l}\text { Polyurethane } \\
\text { Matrix }\end{array}$ & Nanofiller & Content & $\begin{array}{l}\text { Processing } \\
\text { Method }\end{array}$ & $\begin{array}{l}\text { Tensile } \\
\text { Strength }\end{array}$ & $\begin{array}{l}\text { Thermal } \\
\text { Stability }\end{array}$ & $\begin{array}{c}\text { Important } \\
\text { Improvement }\end{array}$ \\
\hline TPU [45] & OMMT & $1.0 \mathrm{wt} \%$ & melt & $\begin{array}{c}\text { Increased } 7 \text { to } \\
27 \mathrm{MPa}\end{array}$ & - & $\mathrm{E}^{\prime}$ increased \\
\hline TPU [46] & OMMT & $5.0 \mathrm{wt} \%$ & melt & $\begin{array}{c}\text { Increased } 488 \text { to } \\
908 \mathrm{KPa} \text { (RPA) }\end{array}$ & - & $\begin{array}{l}\mathrm{G}^{\prime} \text { increased, } \\
5 \mathrm{wt} \% \mathrm{RPT}\end{array}$ \\
\hline TPU [47] & OMMT & $1.0 \mathrm{wt} \%$ & in situ & $\begin{array}{c}\text { Increased } 32 \text { to } \\
47 \mathrm{MPa}\end{array}$ & Increased $10^{\circ} \mathrm{C}$ & $\mathrm{T}_{\mathrm{m}}$ increased \\
\hline WBPU [48] & $\mathrm{A}-\mathrm{CNT}$ & $1.5 \mathrm{wt} \%$ & in situ & $\begin{array}{c}\text { Increased } 7 \text { to } \\
9 \mathrm{MPa}\end{array}$ & - & 54 to 62 hardness \\
\hline PU [49] & SWNT & $2.0 \mathrm{wt} \%$ & in situ & $\begin{array}{c}\text { Increased } 6 \text { to } \\
9 \mathrm{MPa}\end{array}$ & Not changed & $\mathrm{T}_{\mathrm{g}}$ decreased \\
\hline TPU [50] & MWCNT & $2.0 \mathrm{wt} \%$ & melt & $\begin{array}{c}\text { Increased } 2 \text { to } \\
3 \mathrm{MPa}\end{array}$ & Increased $13^{\circ} \mathrm{C}$ & $\begin{array}{l}\text { Increased } \\
\text { modulus }\end{array}$ \\
\hline
\end{tabular}


Table 1. Cont.

\begin{tabular}{|c|c|c|c|c|c|c|}
\hline $\begin{array}{l}\text { Polyurethane } \\
\text { Matrix }\end{array}$ & Nanofiller & Content & $\begin{array}{l}\text { Processing } \\
\text { Method }\end{array}$ & $\begin{array}{l}\text { Tensile } \\
\text { Strength }\end{array}$ & $\begin{array}{l}\text { Thermal } \\
\text { Stability }\end{array}$ & $\begin{array}{c}\text { Important } \\
\text { Improvement }\end{array}$ \\
\hline TPU [19] & TRG/iGO & $1.6 \mathrm{vol} \%$ & solution & $\mathrm{E}^{\prime}$ increased & - & $\begin{array}{l}\times 10 \text { tensile } \\
\text { stiffness }\end{array}$ \\
\hline TPU [51] & GNPs & $2.7 \mathrm{vol} \%$ & solution & decreased & - & - \\
\hline PU [44] & f-GNP & $1.5 \mathrm{wt} \%$ & solution & $\begin{array}{c}\text { Increased } 17 \text { to } \\
23 \mathrm{MPa}\end{array}$ & Increased $30^{\circ} \mathrm{C}$ & $\begin{array}{c}\text { Enhanced shape } \\
\text { memory }\end{array}$ \\
\hline TPU [43] & RGO & 0.1 wt $\%$ & solution & $\begin{array}{c}\text { Increased } 8 \text { to } \\
29 \mathrm{MPa}\end{array}$ & Increased $6^{\circ} \mathrm{C}$ & $\begin{array}{c}410 \% \text { toughness } \\
8 \% \text { hardness }\end{array}$ \\
\hline PU [52] & GO & $1.0 \mathrm{wt} \%$ & solution & Increased $40 \%$ & - & $\begin{array}{c}280 \% \text { Young } \\
\text { modulus ( } 3 \mathrm{wt} \%)\end{array}$ \\
\hline PU [14] & GO & $4.0 \mathrm{wt} \%$ & solution & $\begin{array}{c}\text { Increased } 5 \text { to } \\
27 \mathrm{MPa}\end{array}$ & - & $\begin{array}{c}\times 4.8 \text { Young } \\
\text { modulus }\end{array}$ \\
\hline PU [32] & GNS & $2.0 \mathrm{wt} \%$ & in situ & $\begin{array}{c}\text { Increased } 11 \text { to } \\
36 \mathrm{MPa}\end{array}$ & Increased $40^{\circ} \mathrm{C}$ & $\begin{array}{c}202 \% \text { storage } \\
\text { modulus }\end{array}$ \\
\hline
\end{tabular}

Abbreviations: TPU—-thermoplastic polyurethane; OMMT—organically modified montmorillonite; E'—storage modulus; RPA—rubber process analyzer; $G^{\prime}$-dynamic storage modulus; RPT-rheological percolation threshold; $\mathrm{T}_{\mathrm{m}}$ - melting temperature; WBPU—-waterborne polyurethane; A-CNT_acid treated carbon nanotube; SWNT_-single-walled carbon nanotube; PU—-polyurethane; $\mathrm{T}_{\mathrm{g}}$-glass transition temperature; MWCNT—multiwall carbon nanotube; TRG—-thermally reduced graphene oxide; iGO-isocyanate treated GO; GNPs—graphene nanoplatelets; $\mathrm{f}-\mathrm{GNP}$ - functionalized graphene nanoplatelets; $\mathrm{GO}$ — graphene oxide; $\mathrm{RGO}$-reduced graphene oxide; GNS—graphene nano-sheets.

Segmented polyurethanes contain flexible and rigid chains alternately in the polymer back bone. The precursor of soft flexible segments is polymeric macromolecules with hydroxyl-end groups, while rigid segments are obtained because of reaction diisocyanate with low-molecular diol or diamine. Due to the chemical incompatibility between the two types of segments (soft and hard), segmented polyurethanes are phase separated on a nanoscale. This phenomenon leads to the creation hard and soft domains, in which hard domains (HS) are rich in rigid segments and soft domains (SS) are rich in flexible chains. Hard domains are responsible for mechanical strength and hardness, and on the other hand, soft domains provide elasticity [53]. Furthermore, hard domains act as a physical cross-linking by the so-called reversible cross-links through hydrogen bonding interactions. Therefore, these materials are excellent thermoplastic elastomers (TPUs), which allow them to be processed using thermoplastic machinery such as extrusion and injection molding for techniques. The soft segments provide elastic properties to behave like a rubber at ambient conditions.

The aim of this study is to explore the influence of graphene-like nano structured carbon fillers, RGO (reduced graphene oxide), and GNP (graphene nanoplatelets) on the morphology and proprieties of segmented polyurethane thermoplastic elastomers. The filler dispersion, filler orientation and filler-filler networking (Payne effect) have been carefully studied and compared. Morphology-property correlation has been established. Techniques such as high-resolution transmission electron microscopy (HRTEM), DSC, TGA, XRD, Fourier Transformation Infrared Spectroscopy (FTIR), and UTM have been employed to characterize the morphology and proprieties of the system. Theoretical models have been used to fit the experimental data.

\section{Experimental Section}

\subsection{Chemicals and Materials}

In the following research graphite flakes, Micro 850 (99\% at. C, Asbury Carbons, Asbury, NJ, USA) was used as a precursor to obtain Graphite Oxide (GO). Also, potassium permanganate $\left(\mathrm{KMnO}_{4}\right.$, Stanlab, $\left.>99 \%\right)$, hydrogen peroxide $\left(\mathrm{H}_{2} \mathrm{O}_{2}, 30 \%\right.$ aq. $)$, hydrochloric acid $\left(\mathrm{H}_{2} \mathrm{SO}_{4}, 35-38 \%\right.$ aq. $)$, phosphoric acid $\left(\mathrm{H}_{3} \mathrm{PO}_{4}, 85 \%\right)$, sulfuric acid $\left(\mathrm{H}_{2} \mathrm{SO}_{4}, 96 \%\right)$, ethanol $\left(\mathrm{C}_{2} \mathrm{H}_{5} \mathrm{OH}, 96 \%\right)$, and diethyl ether $\left(\left(\mathrm{C}_{2} \mathrm{H}_{5}\right)_{2} \mathrm{O}\right)$, all from POCh S.A., Poland, were used in GO synthesis. Compressed argon $(\mathrm{Ar},>99 \% \mathrm{~mol}$. $)$ 
was used in thermal reduction of GO to reduced graphene oxide (RGO). Graphene platelets (GNP) were supplied by ACS Materials (Advanced Chemicals Supplier, Medford, OR, USA). Thermoplastic polyester urethane (TPU) 52DE55 (Applicazioni Plastische Industriali S.P.A, Mussolente, Italy) was used as a nanocomposite polymer matrix. $\mathrm{N}, \mathrm{N}$-Dimethylmethanamide (DMF) ((HCON$\left(\mathrm{CH}_{3}\right)_{2}, 99 \%$, POCh S.A., Gliwice, Poland) was used as a solvent in composite preparation.

\subsection{Preparation of $R G O$}

Reduced graphene oxide (RGO) was obtained in two-step synthesis. On the first step, graphite oxide (GO) was obtained using modified Hummer's method described in the following article [54]. On the second step, GO was thermally reduced to RGO at a temperature of $200{ }^{\circ} \mathrm{C}$ and normal pressure for 15 min within argon. The efficiency of reduction was 30\%.

\subsection{Nanocomposites Preparation}

Nanocomposites were prepared by the solvent blending method. TPU was dissolved by adding it to DMF at temperature of $80{ }^{\circ} \mathrm{C}$ with continuously stirring, the final concentration of TPU/DMF solutions was $25 \%$ by weight. Next, the proper amounts of nanofillers was added to prepared solution and was homogenized by high-shear mixer (Omni Macro Homogenizer, $35 \mathrm{~mm}$ mixing head diameter) with $2500 \mathrm{rpm}$ for $30 \mathrm{~min}$. Obtained polymer nanocomposite solutions, with good quality of dispersion, were poured onto Petri pans and the DMF was fully evaporated at $70{ }^{\circ} \mathrm{C}$ for $72 \mathrm{~h}$. The obtained nanocomposites were compression molded (under a pressure of 1 ton) to thin film with $0.7 \mathrm{~mm}$ thickness at the temperature of $195^{\circ} \mathrm{C}$. Press molded films (Table 2) was used later for characterization.

Table 2. Samples designation and nanofillers content.

\begin{tabular}{cc}
\hline Samples & Nanofiller Content/wt $\%$ \\
\hline PURE TPU & $0 \%$ \\
$0.5 \mathrm{TPU} / \mathrm{GNP}$ & $0.5 \%$ \\
$1.0 \mathrm{TPU} / \mathrm{GNP}$ & $1.0 \%$ \\
$2.0 \mathrm{TPU} / \mathrm{GNP}$ & $2.0 \%$ \\
$0.5 \mathrm{TPU} / \mathrm{RGO}$ & $0.5 \%$ \\
$1.0 \mathrm{TPU} / \mathrm{RGO}$ & $1.0 \%$ \\
$2.0 \mathrm{TPU} / \mathrm{RGO}$ & $2.0 \%$ \\
\hline
\end{tabular}

\section{Characterization}

\subsection{FTIR}

Fourier Transformation Infrared Spectroscopy of polyurethane materials has been carried using ThermoElectron Corporation (Waltham, MA, USA) Nicolet 8700 Spectrometer in the Attenuated Total Reflectance (ATR, Gold State II) mode in the range of $500-4000 \mathrm{~cm}^{-1}$. The measurement was carried in standard conditions (normal pressure and at room temperature).

\section{2. $X R D$}

Wide-angle $\mathrm{X}$-ray scattering measurements of nanofillers and polyurethane composites were performed using a Bragg-Brentano X'PERT PHILIPS diffractometer (Malvern Panalytical B. V., Almelo, Netherlands), equipped with a $\mathrm{Cu}$ Anode $\mathrm{X}$-ray tube and diffracted beam monochromator $(40 \mathrm{kV}$, $30 \mathrm{~mA}, \lambda \mathrm{Cu} \mathrm{K} \alpha=0.1542 \mathrm{~nm}$ ). TPU samples were scanned in $2 \theta$ range from $5^{\circ}$ to $35^{\circ}$.

\subsection{TEM}

Microscopy analysis (for nanofiller GNP and RGO) was performed by means of STEM-EDX technique using Transmission Electron Microscope FEI Europe (Eindhoven, The Netherlands), Tecnai 
F20 X-Twin coupled with EDX Spectrometer (Tecnai, Hillsboro, Oregon, USA) (samples were cut in cryo-mode using ultramicrotome). HRTEM (for nanocomposite systems) is from JEOL (Tokyo, Japan), model JEM-2100. The samples were sliced with LEICA EM UC7 Ultra Microtome with cryo-mode (EM FC7, LEICA, Wiesral, Germany) using glass knife. The thickness of the samples was $150 \mathrm{~nm}$ and the slices were deposited on a 200 mesh Cu Grid.

\subsection{TG}

Thermogravimetry (TG; (International Organization for Standardization) ISO 11358) of obtained materials was conducted by Netzsch TG209F3 TG analyzer (NETZSCH, Selb, Germany). Degradation process has been performed in the temperature range from $35^{\circ} \mathrm{C}$ to $700{ }^{\circ} \mathrm{C}$, nitrogen atmosphere with gas flow rate $40 \mathrm{~mL} / \mathrm{min}$, and heating rate $20^{\circ} \mathrm{C} / \mathrm{min}$.

\subsection{DSC}

Differential Scanning Calorimetry (DSC; ISO 11357-1, 11357-3) measurements have been carried by Netzsch DSC209F1 instrument (NETZSCH, Selb, Germany) in the temperature range from $-85^{\circ} \mathrm{C}$ to $250{ }^{\circ} \mathrm{C}$. The samples weight was about $10 \mathrm{mg}$, and analysis was conducted in nitrogen atmosphere with gas flow $40 \mathrm{~mL} / \mathrm{min}$. The samples were pre-heated (1st-heating) to eliminate thermal history, then cooling and 2 nd-heating at rate $10{ }^{\circ} \mathrm{C} / \mathrm{min}$.

\subsection{Mechanical Properties (Dynamic and Static Mode)}

Dynamical Mechanical Analysis (DMA; (American Society for Testing and Materials) ASTM D4065, D7028-07) has been carried by TA Instruments DMA Q800 analyzer (DMA, West Kentucky, PA, USA). Temperature investigation mode has been performed in uniaxial tension mode, in the temperature range $-100-100{ }^{\circ} \mathrm{C}, 1 \mathrm{~Hz}$ frequency amplitude of deformation $20 \mu \mathrm{m}$ and heating rate $4^{\circ} \mathrm{C} / \mathrm{min}$ using liquid nitrogen as cooling medium. Strain sweep analysis for Payne effect investigation has been conducted in three different temperatures $\left(35^{\circ} \mathrm{C}, 55^{\circ} \mathrm{C}\right.$, and $\left.75^{\circ} \mathrm{C}\right)$, in the same tension mode and frequency of deformation, but in the amplitude range from 0.25 to $170 \mu \mathrm{m}$. The dimensions of thin samples were $5.0 \times 5.0 \times 0.7 \mathrm{~mm}^{3}$. Tensile (in static mode) tests were carried out using universal testing machine (UTM) Zwick/Roell Z020 (Zwick, Kennesaw, GA, USA). All of the tests were performed according to ISO 527-1 standard.

\section{Results and Discussions}

\subsection{Characterization of Graphene Nanofillers}

Prepared reduced graphene oxide (RGO) nanofiller possess good exfoliated structures (Figure 1a). Our previous study [55] confirmed that RGO nanofiller consists of about six layers ( $2 \mathrm{~nm}$ height) in a stacking nanostructures. The other nanofiller-graphene nanoplatelets (GNP) possess many defects, as observed in the form of holes within the structure (Figure 1b). GNP are seen as thin flakes with diameters between 2 and $10 \mathrm{~nm}$ in agreement with our previous presented study [56]. The X-ray diffraction analysis was performed on the GNP nanofiller and is characterized by the presence of diffraction maximum at $2 \theta=27^{\circ}$ (Figure 1c) in agreement with the literature report [57]. For RGO nanofiller, we have observed the absence of diffraction maximum, which could be correlated with disordered structure of this material (Figure 1c). 


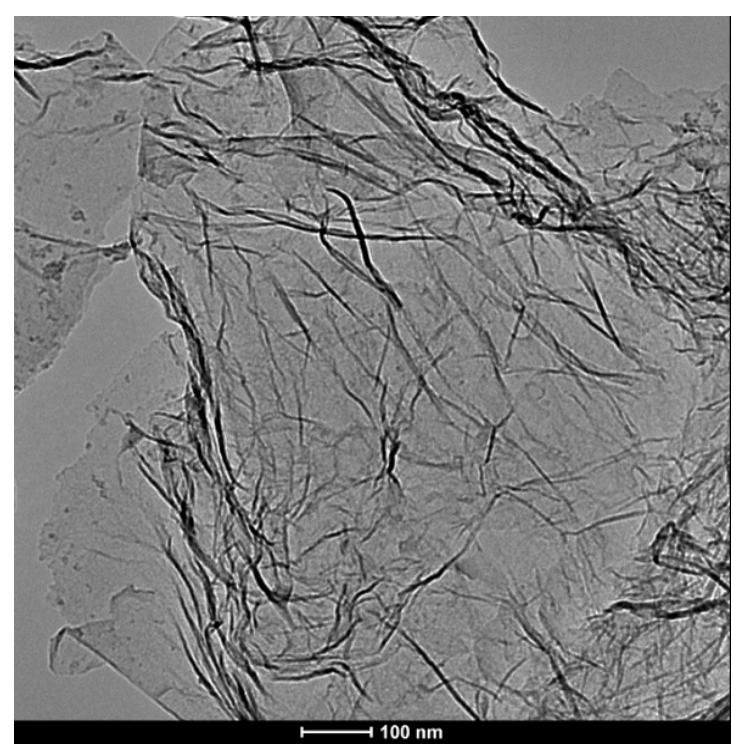

(a)

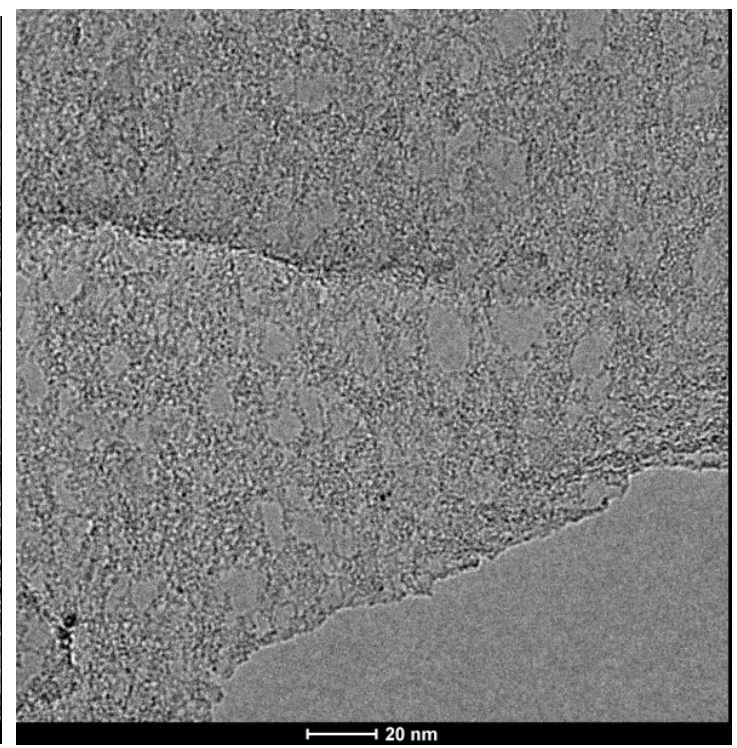

(b)

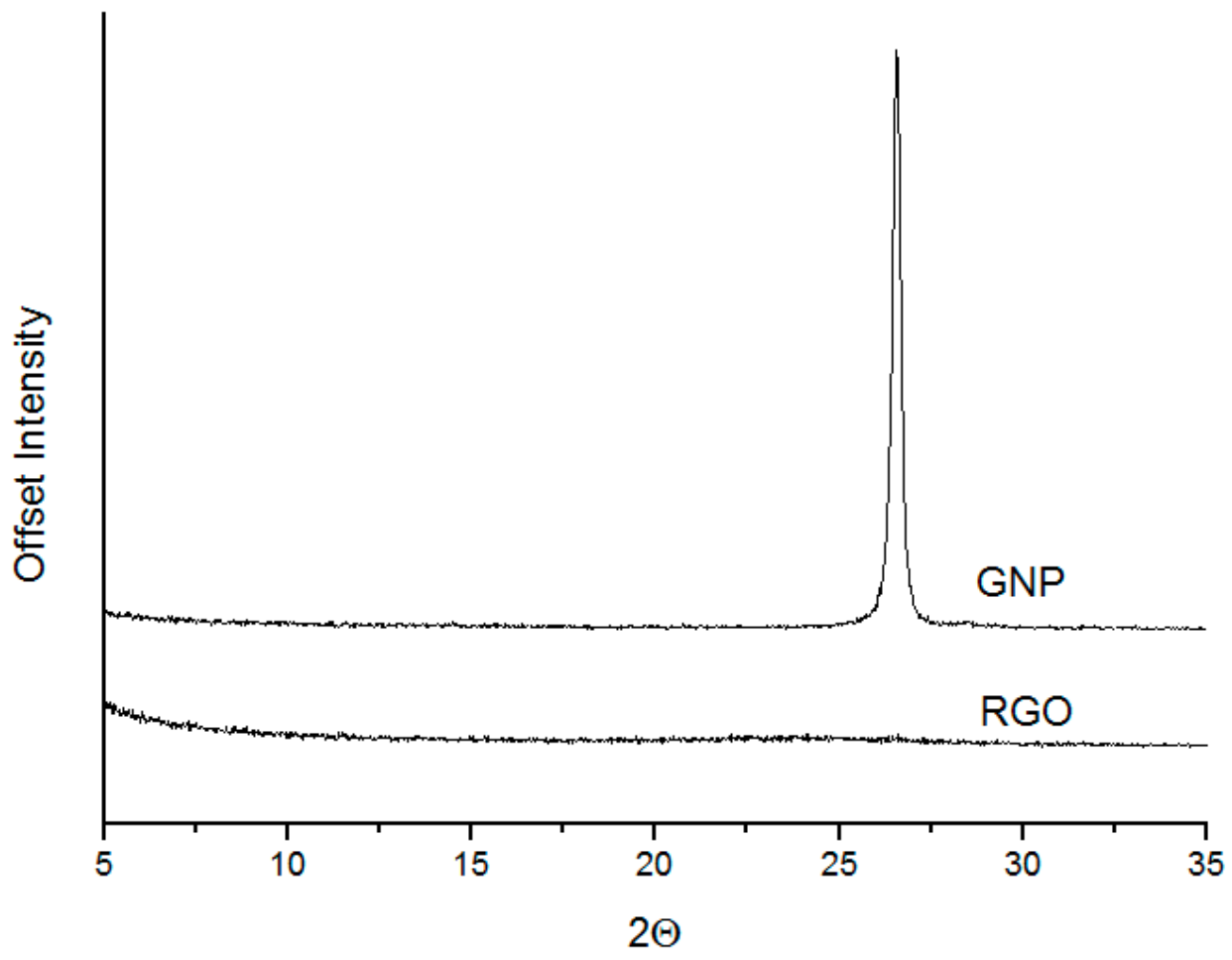

(c)

Figure 1. High resolution Transmission Electron Microscopy (TEM) images of graphene oxide (RGO) (a) and graphene nanoplatelets (GNP) (b) monolayers and Wide-angle X-ray scattering (WAXS) patterns of RGO and GNP nanofillers (c).

\subsection{Characterization of Nanocomposites}

\subsubsection{FTIR Spectroscopy}

Based on the FTIR spectroscopy, we have the interaction between nanofiller and PU segments (soft and hard). The spectra of TPU and modified nanocomposite systems (Figure 2) are similar for both modifications GNP and RGO. The weak absorption peaks, as observed at $3319 \mathrm{~cm}^{-1}$, were assigned 
to stretching vibrations of $\mathrm{N}-\mathrm{H}$ groups that were present in both types of TPU spectra. The wide base of the identified peak of NH stretching may be related to the presence of hydrogen bonds in the TPU and GNP or RGO modified TPU structure. The very strong carbonyl stretching, in the case of obtained TPUs and nanocomposite systems, appeared at $1726 \mathrm{~cm}^{-1}$. The FTIR analysis confirmed that the performed synthesis lead to the generation of obtain TPUs [58].

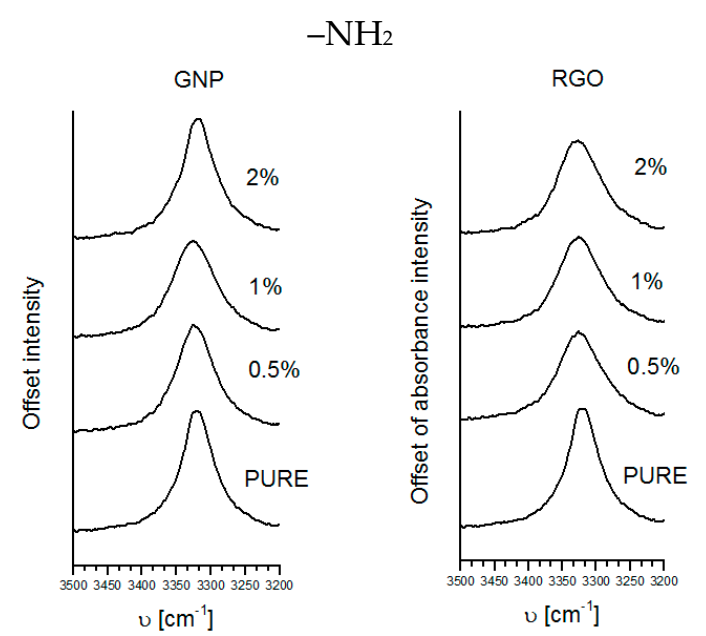

(a)

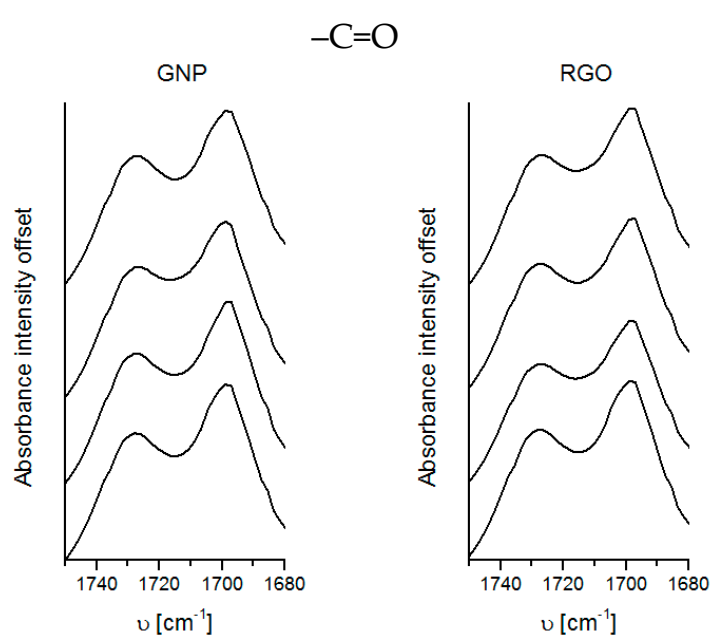

(b)

Figure 2. Fourier Transformation Infrared Spectroscopy (FTIR) spectra's comparison for pure TPU (Thermoplastic polyester urethane) and TPU nanocomposites (a) $-\mathrm{NH}^{2}$ band and $(\mathbf{b})-\mathrm{C}=\mathrm{O}$ band.

\subsubsection{Wide Angle X-ray Diffraction (WAXD)}

Polyurethane matrix (non-modified material) possess good define, long-range ordering, crystalline structure. What is more, these materials exhibit a micro-heterophase structure, which is not visible as diffraction maxima measure using X-ray diffraction. These observations were also confirmed, based on DSC results (see. Section DSC), where soft domain (SS) crystallization and melting point are not visible. What is more, hard domain (HS) connections and bigger agglomerations cause visible diffractogram maximum at $20^{\circ}$ (Figure 3). It was visible hard segment (HS) orientation with the addition of nanofiller into polyurethane matrix. Based on XRD diffraction maxima, lower crystalline phase content is observed at about $20^{\circ}$. This is connected with a lower area of segment interaction with increasing nanofiller content. Introduced nanofillers (RGO or GNP) interact with soft and hard segments to improve the direction of the HS, better separation of these domains and crystallization. For RGO based nanocomposites is visible better ordered structures in comparison to the GNP one. Especially at $17-25^{\circ}$ and $10^{\circ}$ maxima where TPU/GNP nanocomposites possess lower intensity, but maxima are still separated. These behaviors could be connected with different size of nanofiller (higher aspect ratio RGO over GNP), what cause block macromolecules and decrease the rotation and crystal growing direction of hard domain. Second explanation can be connected with higher tendency to infect of hard domain by RGO nanofiller and GNP one reviles in soft domains. What is more, in hard domains, more RGO is observed than for GNP nanocomposite and this present nanofiller influent on selective improvement. Otherworld's nanofiller infect crystallinity of hard domains and block ability to recrystallization. Diffraction curves (Figure 3) show visible maxima of GNP nanofiller what can be related to difficult exfoliation process. 


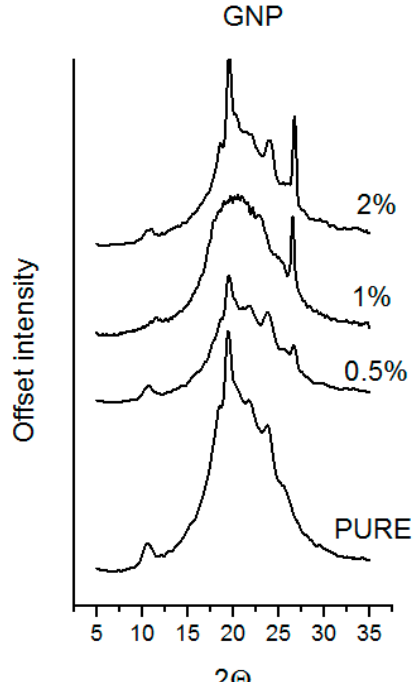

(a)

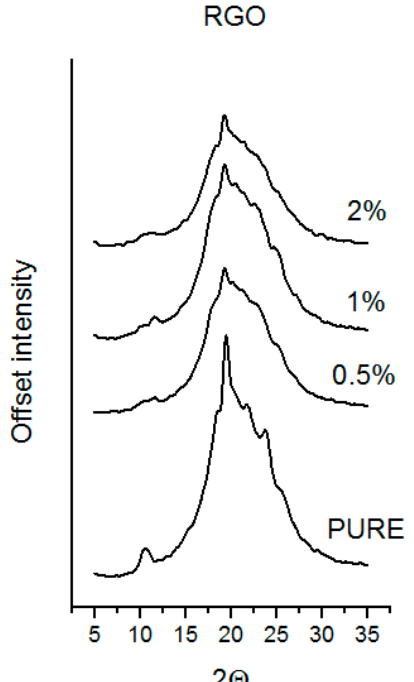

(b)

Figure 3. Diffraction maxima for nanocomposites (a) polyurethane (PU)-GNP and (b) PU-RGO.

\subsubsection{Transmission Electron Microscopy (TEM)}

Based on Transmission Electron Microscopy (TEM) analysis, it was confirmed presents of the nanofiller (RGO or GNP) into polyurethane matrices. This is very important factor to characterize morphology of the nanofiller (size, dispersion) on the nanocomposite systems. Reduced graphene oxide (RGO) and graphene nanoplatelets (Figure 4) have layered structure to e.g., montmorillonite systems [59].

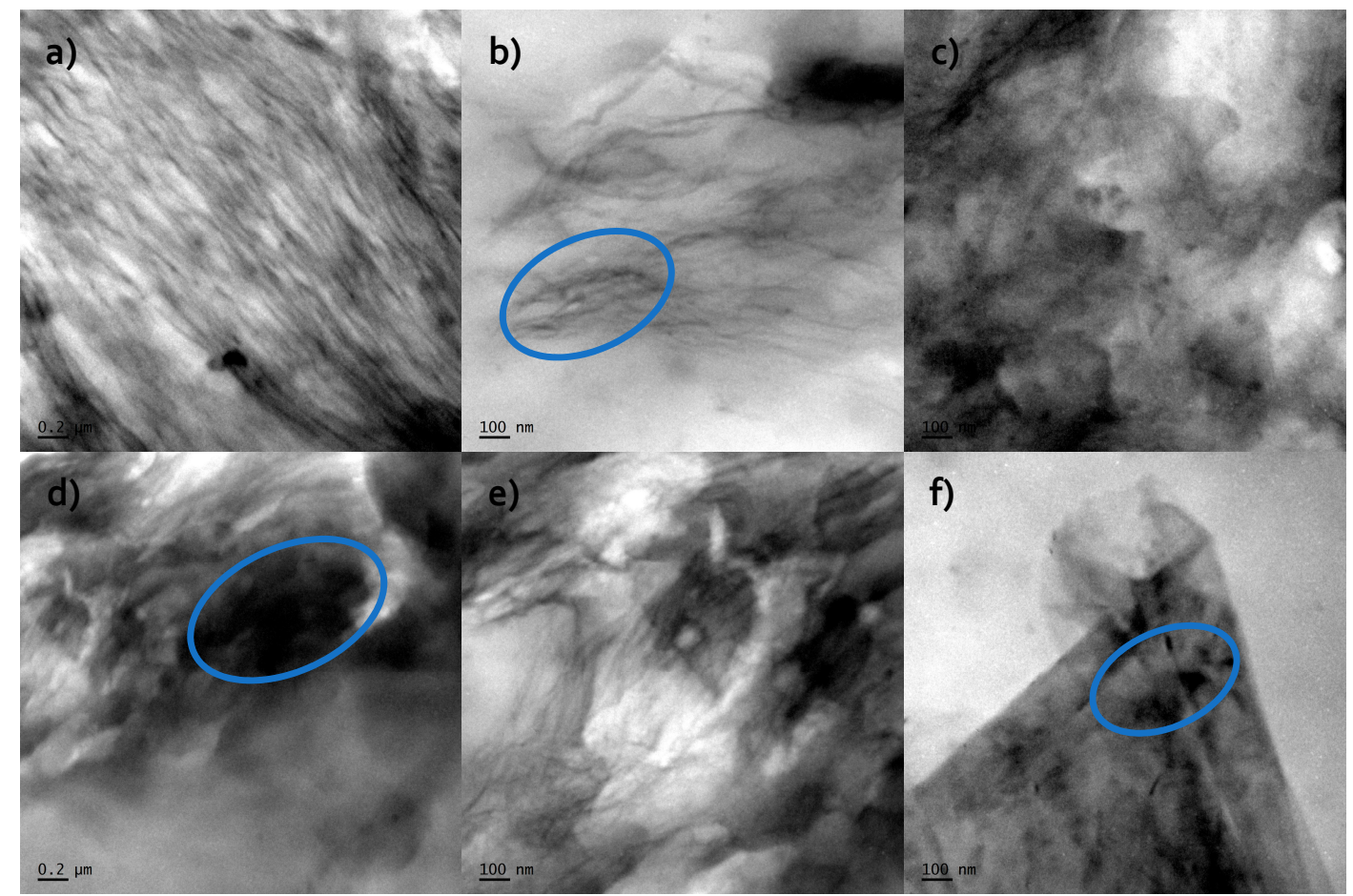

Figure 4. TEM microphotographs of (a) $1.0 \mathrm{TPU} / \mathrm{RGO}$; (b) $1.0 \mathrm{TPU} / \mathrm{RGO}$; (c) $2.0 \mathrm{TPU} / \mathrm{RGO}$; (d) $1.0 \mathrm{TPU} / \mathrm{GNP}$; (e) $1.0 \mathrm{TPU} / \mathrm{GNP}$; and, (f) $2.0 \mathrm{TPU} / \mathrm{GNP}$. 
Long, dark lines represent the characteristic geometry of graphene nanofillers, which are dispersed into PU materials [60]. For TPU/RGO systems, the good dispersion (few layers-thick reduced graphene oxide sheets) obtained what clearly show in the Figure 4a-c. For TPU/GNP systems (Figure 4d-f) the larger agglomerates were observed (about $200 \mathrm{~nm}$ length) in comparison to the RGO filled systems. RGO nanofiller possess better compatibility to the polyurethane matrix (what relates to $-\mathrm{O}-$ or $-\mathrm{OH}$ group on the surface of the nanofiller), and therefore higher dispersion is observed. Classic polymer nanocomposite systems (filled with layer structured nanofillers) can possess intercalated or exfoliated structured [61]. Compare TEM analysis for obtained materials and XRD results (absent of diffraction maxima; describe in Section 4.2.2), exfoliated nanocomposite morphology was confirmed.

\subsubsection{Thermogravimetric Analysis (TG)}

Segmented polyurethanes based on microheterophase structure possess different degradation temperature of hard (HS) and soft (SS) segments. Generally, hard segments degradate at lower temperatures in comparison to the degradation of soft domains of polyurethane materials. This characteristic was registered on DTG thermograms: two maximum peaks for maximum degradation temperatures for $\mathrm{HS}$ and SS. At degradation temperature rage, partially mixing (above $120^{\circ} \mathrm{C}$ ) of hard and soft domains could be possible. What is more, one maximum on DTG curve determines absent of phase separation of the PU segments.

Based on TG analysis, it was possible to verify phase separation in polyurethane system that was caused by nanofiller. Graphene based nanofiller can thermally protect the polyurethane matrix, especially at local regions. It was found for obtained nanocomposites, that high thermal conductivity of graphene, allows for effective heat transfer, causing a reduction of over-heating of hard segment domains, what is visible as higher degradation temperature of filled materials. Other possible mechanism of better thermal stability of the systems is based on lower phase separation of soft (SS) and hard segments (HS), and higher mobility of soft segments and easy transfer (dissipation) heat into polyurethane matrix. Addition of nanofiller, which reduce SS and HS mobility influent on phase separation of these systems.

The degradation temperature for PURE TPU starts at $328^{\circ} \mathrm{C}\left(\mathrm{T}_{\text {onset }}\right)$ (Figure 5). Decomposition temperature ( $\left.\mathrm{T}_{\text {onset }}\right)$ shifts to $5-6{ }^{\circ} \mathrm{C}$ higher values, for RGO based nanocomposites, and $8-10{ }^{\circ} \mathrm{C}$ for TPU/GNP systems (Table 3). For obtained systems, the maximum of degradation temperature ( $\mathrm{T}_{\mathrm{DTG}-\mathrm{HS}}$ ) shifts to the higher temperatures for modified systems (max. $12{ }^{\circ} \mathrm{C}$ for $0.5 \%$ RGO and $1.0 \%$ GNP-TPU filled nanocomposites). The degradation temperature of soft segments ( $\left.\mathrm{T}_{\mathrm{DTG}-\mathrm{SS}}\right)$ for all of the modified materials is similar to the degradation temperature of the PURE TPU system (Table 3). It is also visible as an increasing in mass residue with addition of nanofiller to polyurethane nanocomposites (Table 3).
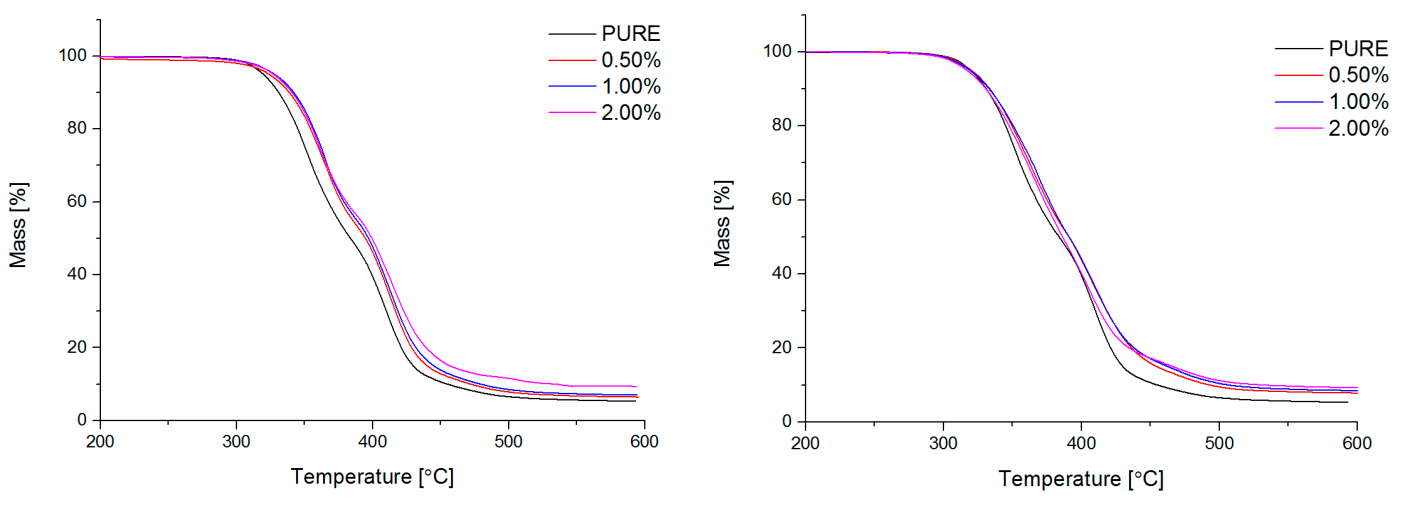

Figure 5. Cont. 


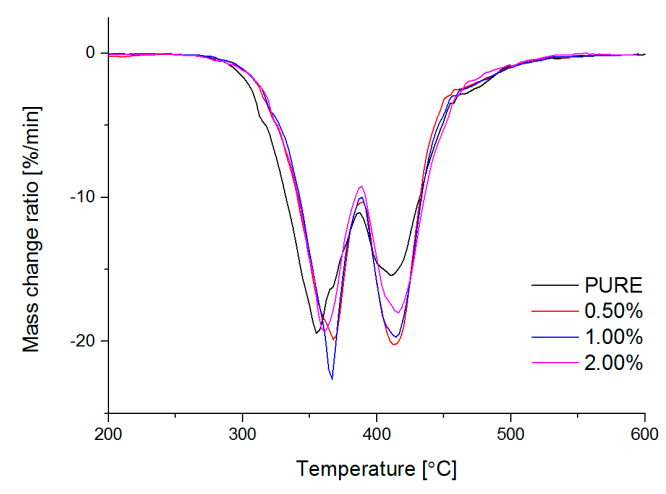

(a)

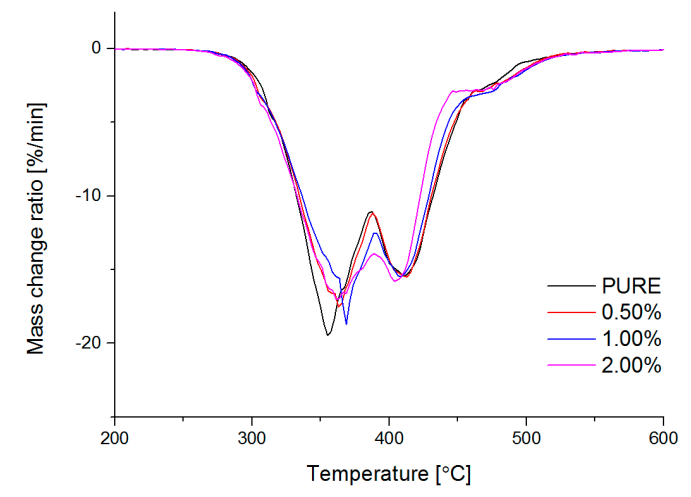

(b)

Figure 5. Thermogravimetry (TG) curves \%mass vs. Temperature and DTG vs. temperature for TPU and TPU RGO (a)/GNP (b) nanofiller systems.

Table 3. Thermogravimetric results for TPU (Thermoplastic polyester urethane) and TPU RGO/GNP nanofiller systems.

\begin{tabular}{|c|c|c|c|c|c|c|c|c|c|}
\hline Composite & $\begin{array}{l}\mathrm{T}_{\text {onset }} \\
\left({ }^{\circ} \mathrm{C}\right)\end{array}$ & $\begin{array}{l}\mathrm{T}_{95 \%} \\
\left({ }^{\circ} \mathrm{C}\right)\end{array}$ & $\begin{array}{l}\mathrm{T}_{90 \%} \\
\left({ }^{\circ} \mathrm{C}\right)\end{array}$ & $\begin{array}{l}\mathrm{T}_{50 \%} \\
\left({ }^{\circ} \mathrm{C}\right)\end{array}$ & $\begin{array}{c}\text { T }_{\text {DTG-HS }} \\
\left({ }^{\circ} \mathrm{C}\right)\end{array}$ & $\begin{array}{l}\text { V }_{\text {DTG-HS }} \\
\text { (\%/Min) }\end{array}$ & $\begin{array}{c}\text { T }_{\text {DTG-SS }} \\
\left({ }^{\circ} \mathrm{C}\right)\end{array}$ & $\begin{array}{l}V_{\text {DTG-SS }} \\
\text { (\%/Min) }\end{array}$ & $\begin{array}{l}\text { Remains } \\
\text { (\% Mass) }\end{array}$ \\
\hline PURE TPU & 328 & 321 & 333 & 387 & 356 & -19.5 & 411 & -15.5 & 5.5 \\
\hline $0.5 \mathrm{TPU} / \mathrm{RGO}$ & 333 & 324 & 339 & 395 & 368 & -19.9 & 413 & -20.2 & 6.5 \\
\hline 1.0 TPU/RGO & 333 & 328 & 342 & 397 & 366 & -22.8 & 415 & -19.7 & 7.0 \\
\hline 2.0 TPU/RGO & 334 & 327 & 341 & 399 & 361 & -19.3 & 416 & -18.0 & 9.4 \\
\hline $0.5 \mathrm{TPU} / \mathrm{GNP}$ & 326 & 320 & 333 & 391 & 364 & -17.7 & 413 & -15.5 & 7.5 \\
\hline $1.0 \mathrm{TPU} / \mathrm{GNP}$ & 323 & 319 & 333 & 391 & 368 & -18.7 & 408 & -15.5 & 8.2 \\
\hline 2.0 TPU/GNP & 328 & 317 & 331 & 386 & 362 & -17.1 & 404 & -15.8 & 9.0 \\
\hline
\end{tabular}

\subsubsection{Differential Scanning Calorimetry (DSC)}

For many group of polymers, which possess semicrystalline structure, the incorporation of nanofiller causes changes in the crystallization degree, size of the crystalline aggregates, and changes in crystallization rate and in the maximum crystallization temperature $\left(\mathrm{T}_{\mathrm{m}(\mathrm{max})}\right)$ observed on DSC thermograms [59]. What is more, GNP nanofiller promotes the crystallization process into polyurethane matrix what was investigated using other polymer matrices e.g., polyamide 6 [62]. Additionally, the presence of nanofiller may also affect the rate of crystallization [61]. It was noticed that higher crystallization temperatures $\left(\mathrm{T}_{\max } \approx 14-40{ }^{\circ} \mathrm{C}\right.$ ) (Table 4 ) were registered for nanocomposites containing GNP and RGO nanofiller. The addition of nanofiller causes different curve character for melting point peaks. For PURE TPU material is visible peak at $212-216{ }^{\circ} \mathrm{C}$ connected with melting point of crystalline reign from hard segments (HS). In the DSC curve, close to the $0{ }^{\circ} \mathrm{C}$, it is a visible characteristic step that is connected with glass transition temperature $\left(\mathrm{T}_{\mathrm{g}}\right)$. This parameter was calculated and described, based on DMA study (Section 4.2.6) $\left[\mathrm{T}_{\mathrm{g}} \approx-27{ }^{\circ} \mathrm{C}\right.$ (for PURE TPU) to $-31^{\circ} \mathrm{C}$ (for $2.0 \mathrm{TPU} / \mathrm{GNP}$ )]. For PURE TPU polyurethane matrix, DSC curve indicates that there are no crystalline regions within the soft domain, while at $216{ }^{\circ} \mathrm{C}$ there is a maximum corresponding to the melting of crystalline hard domains $\left(\mathrm{T}_{\mathrm{m}}\right)$. Thus, the polyurethane matrix is composed of two amorphous regions, which are arranged in rigid segments consisting of hard domains. Polyurethane matrix possesses soft and hard segments what was also confirmed using XRD investigation and correlate with DSC results. The visibility of diffraction maxima's in XRD studies (Section 4.2.2) indicate that the ordering of polymer chains is long-range, indicating that the contents of the rigid segments in the matrix are above 25\%-the hard domain (HS), resulting in larger crystalline agglomerates. GNP nanofiller add into polyurethane matrix influent on heating thermograms (Figure 6), where multi maximum peaks are visible in the temperature range $190-220^{\circ} \mathrm{C}$. Based on melting theory $[14,61]$, the maximum of the peak at lower temperature relates to smallest crystalline areas and for larger crystalline form the 
temperature is higher. The effect of nanofillers (GNP and RGO) on crystallization of hard domains (HS) has also been investigated. The influence of particles on the crystallization process is clearly visible (Figure 7). The DSC curves of the TPU/GNP composites show an increase in the crystallization temperature $\left(T_{c}\right)$, which is related to the GNP activity as nucleation process in the heterocrystallization by increasing its temperature. In the TPU/RGO nanocomposites, the crystallization temperatures have practically remained unchanged, indicating its less influential factor.

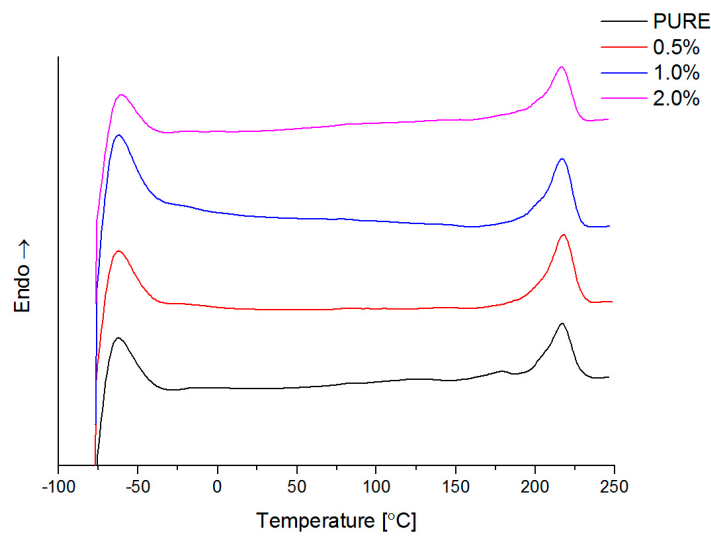

(a)

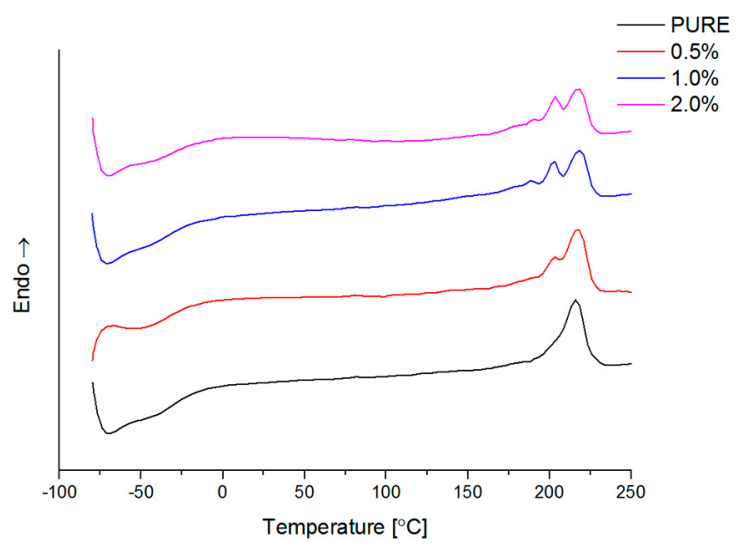

(b)

Figure 6. Thermograms for nanocomposites RGO (a); GNP (b) (second heating) and PURE TPU system.

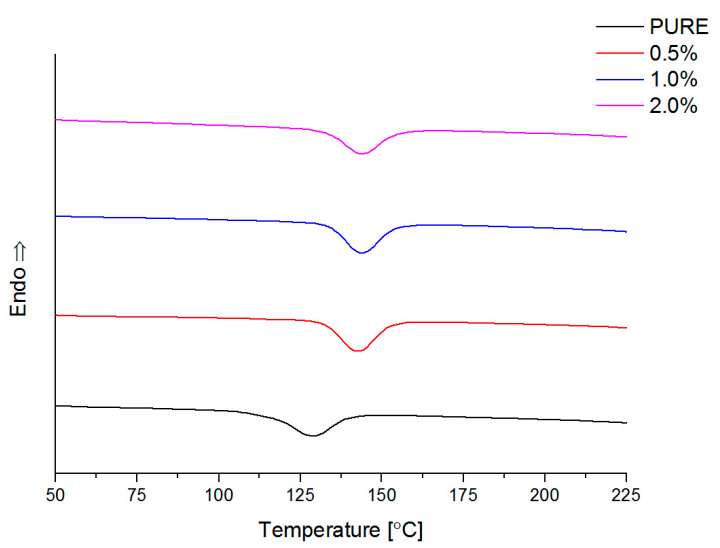

(a)

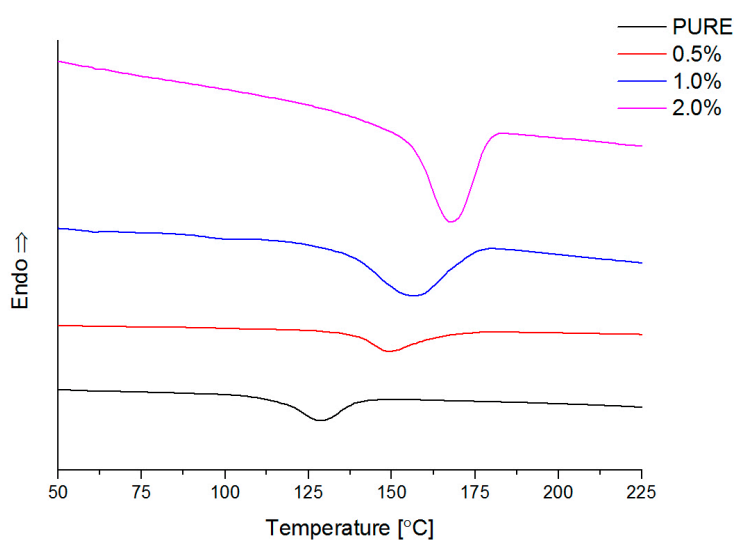

(b)

Figure 7. Thermograms for nanocomposites RGO (a); GNP (b) (cooling) and PURE TPU system.

Table 4. Differential Scanning Calorimetry (DSC) parameters, $\mathrm{T}_{\mathrm{m}}$-melting temperature, $\Delta \mathrm{H}_{\mathrm{m}}$-enthalpy of melting, $\mathrm{T}_{\mathrm{c}}-$ crystallization temperature, $\Delta \mathrm{H}_{\mathrm{c}}$-enthalpy of crystallization for TPU (PURE), and TPU RGO/GNP nanofiller systems.

\begin{tabular}{ccccc}
\hline Materials & $\mathbf{T}_{\mathbf{m}}(\mathbf{M a x})\left({ }^{\circ} \mathbf{C}\right)$ & $\Delta \mathbf{H}_{\mathbf{m}}(\mathbf{J} / \mathbf{g})$ & $\mathbf{T}_{\mathbf{c}}(\mathbf{M a x})\left({ }^{\circ} \mathbf{C}\right)$ & $\Delta \mathbf{H}_{\mathbf{c}}(\mathbf{J} / \mathbf{g})$ \\
\hline PURE TPU & 216 & 11.9 & 129 & -18.2 \\
$0.5 \mathrm{TPU} / \mathrm{GNP}$ & $203 ; 217$ & 11.9 & 149 & -18.7 \\
$1.0 \mathrm{TPU} / \mathrm{GNP}$ & $189 ; 203 ; 219$ & 12.5 & 157 & -18.6 \\
$2.0 \mathrm{TPU} / \mathrm{GNP}$ & $191 ; 204 ; 218$ & 12.8 & 169 & -16.3 \\
$0.5 \mathrm{TPU} / \mathrm{RGO}$ & 219 & 17.8 & 143 & -17.8 \\
$1.0 \mathrm{TPU} / \mathrm{RGO}$ & $200 ; 218$ & 15.6 & 144 & -16.6 \\
$2.0 \mathrm{TPU} /$ RGO & $192 ; 201 ; 217$ & 11.4 & 144 & -17.1 \\
\hline
\end{tabular}




\subsubsection{Dynamic Mechanical Analysis (DMA) and Mechanical Properties}

Dynamic mechanical properties were analyzed for all of the obtained materials. Based on curve behavior, it was visible high hard segments (HS) content for non-modified material (PURE TPU) (Figures 8-10). For modified systems (RGO and GNP) with increasing nanofiller content, higher values of $\mathrm{E}^{\prime}$ were obtained (Figure 8, Table 5) in a wide range of temperatures.

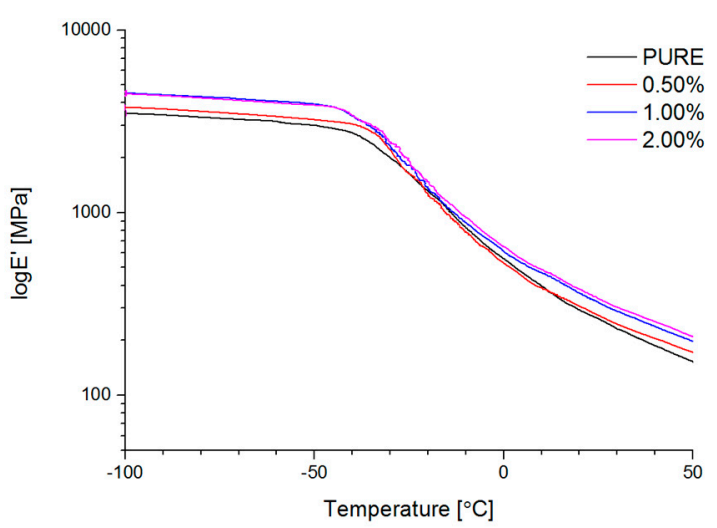

(a)

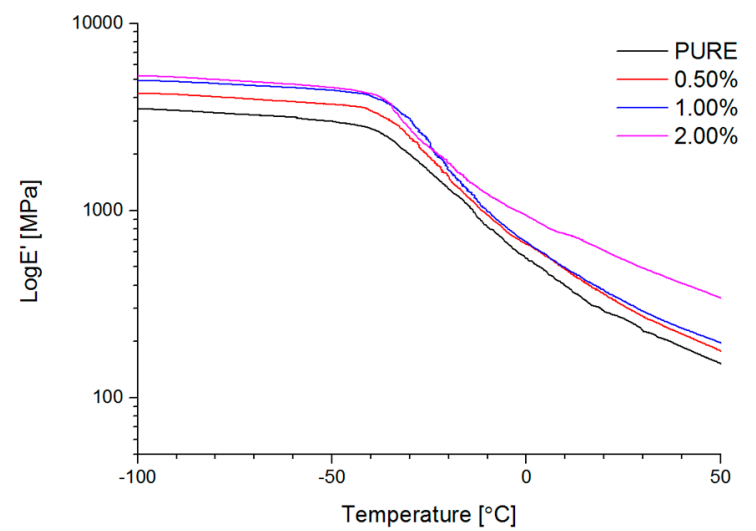

(b)

Figure 8. Storage modulus ( $\left.\mathrm{E}^{\prime}\right)$ vs. temperature for TPU and TPU RGO (a)/GNP (b) nanofiller systems.

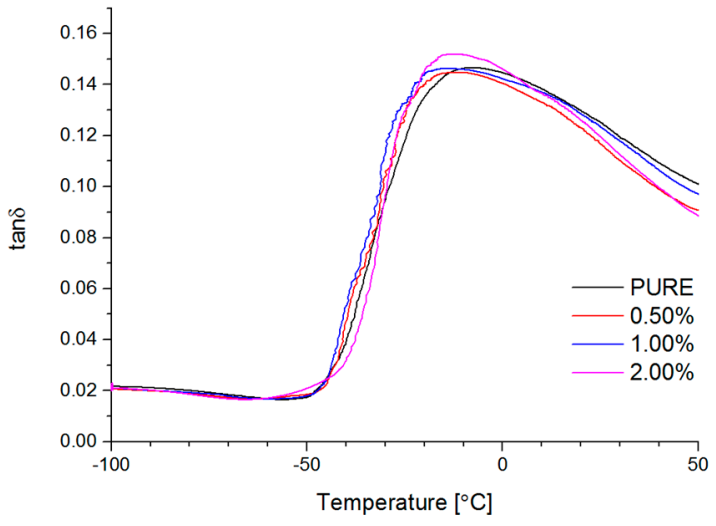

(a)

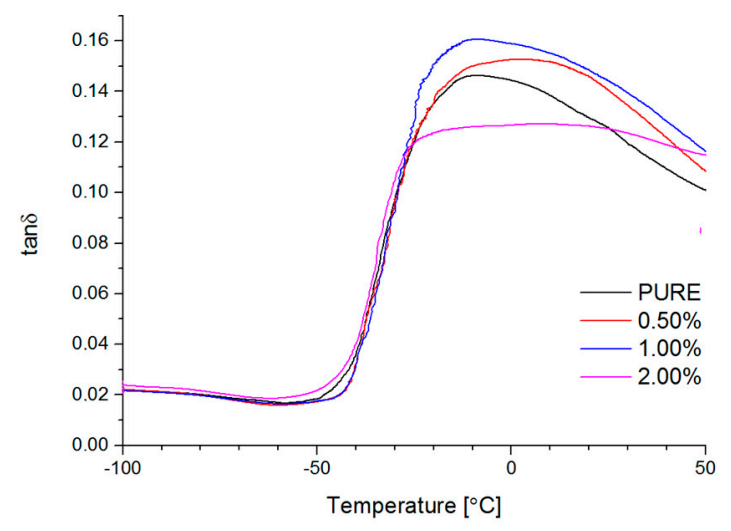

(b)

Figure 9. Loss tangent $(\tan \delta)$ vs. temperature for TPU and TPU RGO (a)/GNP (b) nanofiller systems.

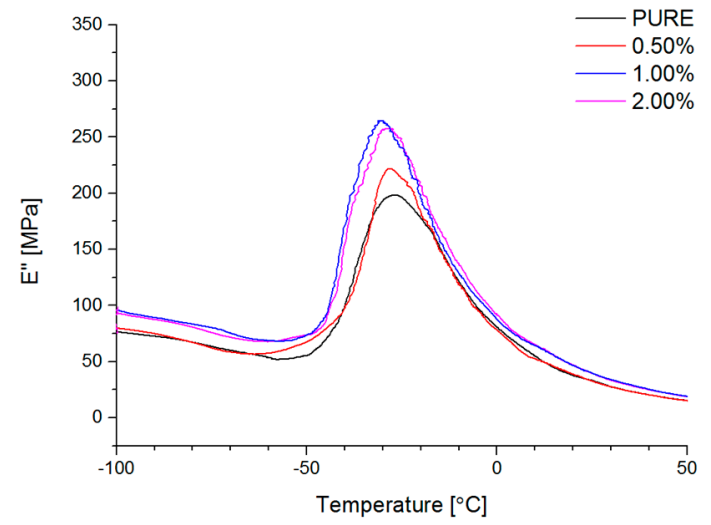

(a)

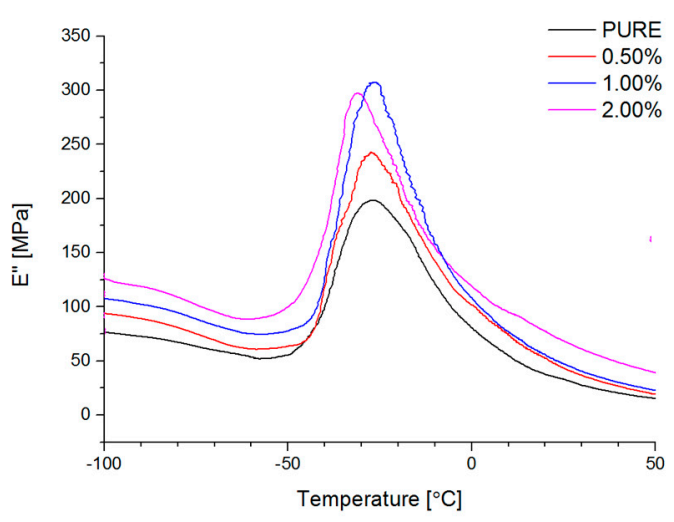

(b)

Figure 10. Loss modulus ( $\left.E^{\prime \prime}\right)$ vs. temperature for TPU and TPU RGO (a)/GNP (b) nanofiller systems. 
Table 5. Dynamic Mechanical Analysis (DMA) results for TPU and TPU RGO/GNP nanofiller systems.

\begin{tabular}{cccccc}
\hline Composites & $\mathbf{E}^{\prime} \mathbf{7 0}_{\mathbf{7 0}}(\mathbf{G P a})$ & $\left.\mathbf{E}^{\prime}{ }_{\mathbf{3 5}} \mathbf{( G P a}\right)$ & $\mathbf{E}_{\mathbf{2 5}}^{\prime}(\mathbf{G P a})$ & $\mathbf{T}_{\mathbf{g}}\left({ }^{\circ} \mathbf{C}\right) / \mathbf{E}^{\prime \prime}$ & $\delta_{\max }(\mathbf{M P a})$ \\
\hline PURE TPU & 3.2 & 2.4 & 0.3 & -27 & $30.4 \pm 1.5$ \\
$0.5 \mathrm{TPU} / \mathrm{GNP}$ & 3.9 & 3.0 & 0.3 & -27 & $32.7 \pm 1.6$ \\
1.0 TPU/GNP & 3.0 & 2.3 & 0.2 & -26 & $36.8 \pm 1.8$ \\
2.0 TPU/GNP & 4.9 & 3.7 & 0.5 & -31 & $39.1 \pm 2.0$ \\
0.5 TPU/RGO & 3.5 & 2.8 & 0.3 & -28 & $37.1 \pm 1.9$ \\
1.0 TPU/RGO & 4.2 & 2.9 & 0.3 & -30 & $39.5 \pm 2.0$ \\
2.0 TPU/RGO & 4.1 & 3.0 & 0.3 & -29 & $44.0 \pm 2.2$ \\
\hline
\end{tabular}

Interesting information can derive from $\tan \delta$ versus temperature at the $\mathrm{T}_{\mathrm{g}}$ region. There is only a slight change of $\mathrm{T}_{\mathrm{g}}$ value of TPU nanocomposite in comparison to the PURE TPU (Figure 9). Tangent $\delta$ peak values slightly decrease (from 0.15 to 0.12 ), especially for $2 \mathrm{wt} \% \mathrm{GNP}$, which can be related to less damping behavior of GNP filled TPU [63].

Mechanical properties of polyurethane nanocomposite materials, in the static mode, were presented in the Table 5. With an increasing amount of nanofiller (both RGO and GNP), the tensile strength of modified materials is higher in comparison to the pure TPU matrix. Addition of $2 \mathrm{wt} \%$ RGO into polyurethane causes, higher values of tensile strength $\left[\delta_{\max }\right]$ about $30 \%$ and equal $44 \%$, for GNP nanofiller and for RGO modification, respectively. RGO nanofiller enhanced mechanical properties of polyurethane matrix more in comparison to the GNP one. This is due to the presence of functional group on the surface of the RGO nanofiller, which relates to an increased compatibility to the matrix. These results correspond to the Santosh Kumar Yadav et al. studies [44]. The authors also confirmed that the best mechanical properties for polyurethane nanocomposites, containing functionalized graphene nanoplatelets (f-GNP), are registered for the same amount of the nanofiller in the matrix.

\subsubsection{Payne Effect Analysis}

The results of dynamic strain scan analysis have shown that the storage modulus ( $\left.\mathrm{E}^{\prime} / \mathrm{MPa}\right)$ of nanocomposite systems increased with nanofiller (RGO or GNP) loadings (Figure 11, Table 5), and also show a similar trend for different nanofiller content. The unfilled polyurethane matrix does not display significant changes in storage modulus with strain amplitude (Figure 11). Introducing nanofiller into the PU component causes an increase in storage modulus, which is especially visible for samples with $1 \mathrm{wt} \%$ and $2 \mathrm{wt} \%$ (GNP and RGO), where these amount of nanofiller give higher values of $\mathrm{E}^{\prime}$ and visible drop with the strain amplitude (Tables 5-7). For the same temperature investigation study, the highest value of $\mathrm{E}^{\prime}$ possessed for nanocomposite system stain $2 \mathrm{wt} \%$ of GNP modificator (416 MPa for 2.0 TPU/GNP, in comparison to the PURE TPU storage modulus equal $87 \mathrm{MPa}$, Table 7). With an increasing temperature $\left(35^{\circ} \mathrm{C}, 55^{\circ} \mathrm{C}, 75^{\circ} \mathrm{C}\right)$, the storage modulus $\left(\mathrm{E}^{\prime}\right)$ possesses is lower for unfilled and filled materials (for both used nanofillers). It was observed that in all nanocomposite materials, the amplitude of the Payne effect decreases with an increasing temperature, which is connected with the weakening of filler-filler interactions [64]. Payne effect is widely characterized as filler dispersion and filler network in elastomeric polymer matrix [65]. This effect is described as changes of storage modulus ( $\mathrm{E}^{\prime} / \mathrm{MPa}$ ) filled materials at small strain amplitude, as compared to the non-filled polymeric materials. Strain amplitude sensitivity is considered as a typical non-viscoelastic response in the filled materials. The reduction of storage modulus $\left(E^{\prime}\right)$ with strain $(\varepsilon / \%)$, increasing amplitude is also characteristic for composite or nanocomposite materials [66]. Payne effect is also connected to the formation of filler network by filler-filler and filler-matrix interactions [65]. 

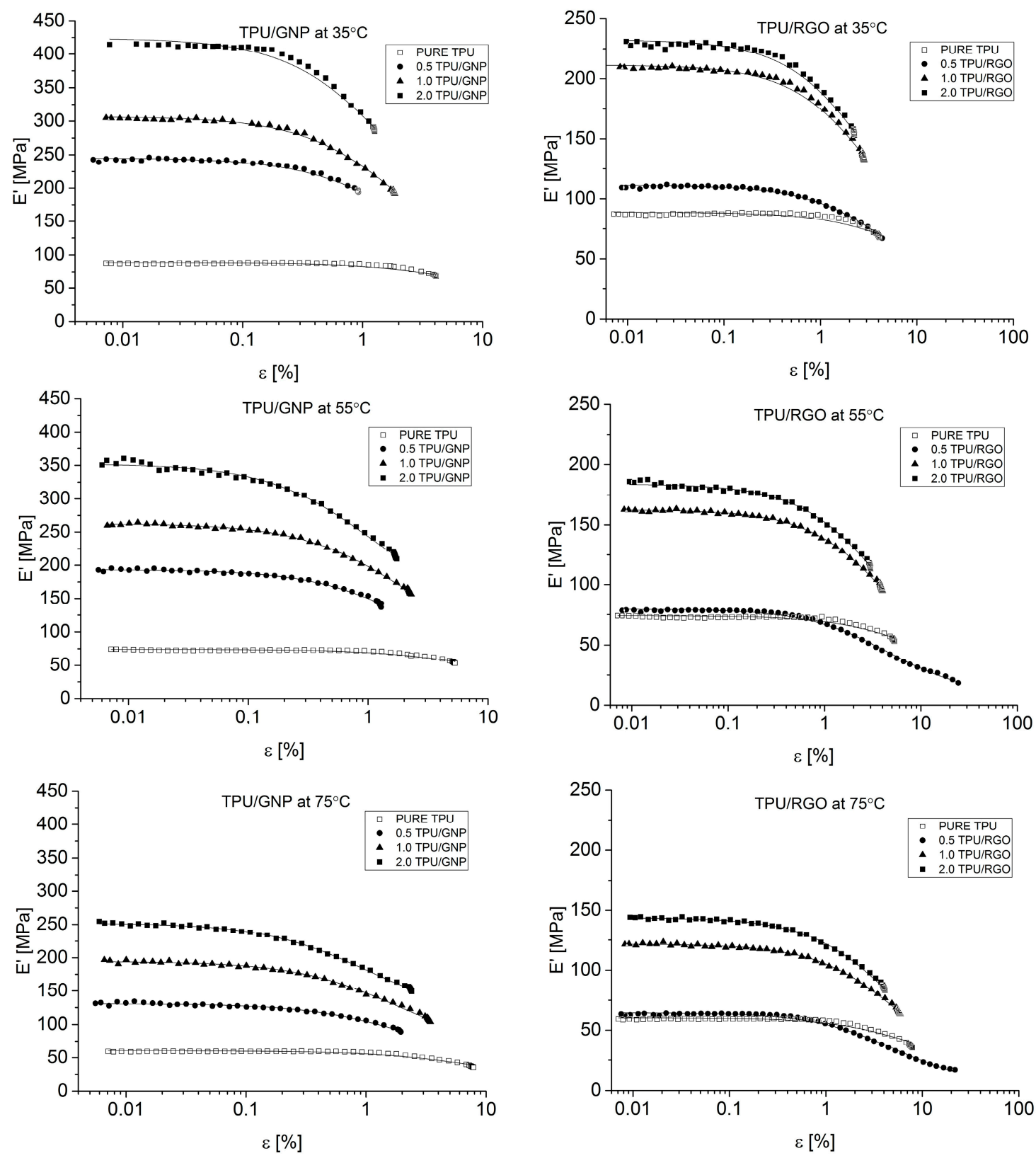

Figure 11. Payne effect comparison based on storage modulus $\left(\mathrm{E}^{\prime} / \mathrm{MPa}\right)$ vs. strain $(\varepsilon / \%)$ changes.

Table 6. DMA (Dynamical Mechanical Analysis) results for TPU and TPU RGO/GNP nanofiller systems.

\begin{tabular}{cccccc}
\hline \multirow{2}{*}{ Nanofiller Content [\% of Weight] } & \multicolumn{2}{c}{$\mathbf{E}^{\prime}{ }_{\text {rel }} 35^{\circ} \mathbf{C}$} & \multicolumn{2}{c}{$\mathbf{E}_{\text {rel }}^{\prime} \mathbf{2 5}{ }^{\circ} \mathbf{C}$} \\
\cline { 2 - 5 } & GNP & RGO & GNP & RGO \\
\hline 0.5 & 1.25 & 1.17 & 1.17 & 1.04 \\
1.0 & 0.97 & 1.20 & 0.68 & 1.21 \\
2.0 & 1.54 & 1.24 & 2.07 & 1.27 \\
\hline
\end{tabular}


Table 7. Payne effect comparison based on storage modulus changes.

\begin{tabular}{|c|c|c|c|c|c|c|c|c|c|}
\hline \multirow[b]{2}{*}{ Composites } & \multicolumn{3}{|c|}{$35^{\circ} \mathrm{C}$} & \multicolumn{3}{|c|}{$55^{\circ} \mathrm{C}$} & \multicolumn{3}{|c|}{$75^{\circ} \mathrm{C}$} \\
\hline & $\begin{array}{c}\mathrm{E}_{0} \\
(\mathrm{MPa})\end{array}$ & $\begin{array}{c}\mathrm{E}_{\infty} \\
(\mathrm{MPa})\end{array}$ & $\begin{array}{c}\Delta \mathrm{E} \\
(\mathrm{MPa})\end{array}$ & $\begin{array}{c}\mathrm{E}_{0} \\
(\mathrm{MPa})\end{array}$ & $\begin{array}{c}\mathrm{E}_{\infty} \\
(\mathrm{MPa})\end{array}$ & $\begin{array}{c}\Delta \mathrm{E} \\
(\mathrm{MPa})\end{array}$ & $\begin{array}{c}\mathrm{E}_{0} \\
(\mathrm{MPa})\end{array}$ & $\begin{array}{c}\mathrm{E}_{\infty} \\
(\mathrm{MPa})\end{array}$ & $\begin{array}{c}\Delta \mathrm{E} \\
(\mathrm{MPa})\end{array}$ \\
\hline PURE TPU & 87 & 87 & - & 74 & 74 & - & 59 & 59 & - \\
\hline $0.5 \mathrm{TPU} / \mathrm{GNP}$ & 240 & 197 & 43 & 193 & 154 & 39 & 134 & 106 & 28 \\
\hline $1.0 \mathrm{TPU} / \mathrm{GNP}$ & 304 & 228 & 76 & 263 & 194 & 69 & 196 & 144 & 52 \\
\hline $2.0 \mathrm{TPU} / \mathrm{GNP}$ & 416 & 314 & 102 & 358 & 241 & 117 & 248 & 181 & 67 \\
\hline $0.5 \mathrm{TPU} / \mathrm{RGO}$ & 110 & 98 & 12 & 79 & 69 & 10 & 64 & 55 & 9 \\
\hline $1.0 \mathrm{TPU} / \mathrm{RGO}$ & 209 & 179 & 30 & 162 & 136 & 26 & 121 & 106 & 15 \\
\hline $2.0 \mathrm{TPU} / \mathrm{RGO}$ & 231 & 193 & 38 & 186 & 150 & 36 & 144 & 119 & 25 \\
\hline
\end{tabular}

\section{Conclusions}

Based on this study it was successfully obtained polyurethane nanocomposites containing reduced graphene oxide (RGO) or graphene nanoplatelets (GNP). The addition of RGO or GNP undoubtedly influenced investigated properties of the polyurethane matrix.

The authors showed the interaction behavior of the nanofillers with the polyurethane matrix by using spectroscopic and diffraction investigation. Morphology investigation confirmed good exfoliation nanoparticles into the polyurethane matrix and shows a better compatibly of RGO nanofiller to the matrix, in comparison to the GNP (where higher agglomeration of this nanofiller is observed, Figure 4d). Phase transition investigation gives information about the effect on melting and crystallization behavior, where GNP nanofiller causes an increased crystallization temperature of the nanocomposite systems. The storage modulus $\left(\mathrm{E}^{\prime}\right)$ of nanocomposites containing TPU/GNP materials significantly increased in comparison to the non-modified (PURE TPU) material. The modulus and thermal stability of the TPU/GNP (RGO) nanocomposites at $2 \mathrm{wt} \%$ nanofiller loading are higher, especially above glass transition temperature $\left(\mathrm{T}_{\mathrm{g}}\right)$, respectively, than those of the PURE TPU material. It is seen (Table $5 ; \delta_{\max }$ ) that the addition of the nanofillers improves the mechanical strength of TPU matrix. Enhanced mechanical properties were observed when add maximum $2 \mathrm{wt} \%$ of nanofiller and higher tensile strength properties obtain for RGO nanofiller in comparison to the GNP modificator.

Both nanofillers, GNP and RGO, enhanced the mechanical and thermal properties of the TPU material. Furthermore, it should be highlighted that by using RGO and GNP nanofiller, the Payne effect is visible for obtained nanocomposite systems. It is demonstrated that different Payne effect behavior is visible for commercial graphene nanoplatelets (GNP) and synthesized reduced graphene oxide (RGO) nanofiller. We could observe agglomeration (strong filler/filler interaction) at higher filler loading, which was evidenced by the high Payne effect. When comparing with results in literature [67] based on TPU matrix and the same amount of filler, nanocomposites with a good balance between thermal and mechanical properties were achieved in this study. The authors believe that these industries based materials could be easily applied in many fields, due to their enhanced properties.

Author Contributions: Michał Strankowski and Piotr Korzeniewski conceived, designed, performed the experiments; Anu A. S. performed the TEM experiments; Justyna Strankowska analysed and fitted the DMA/ Payne effect experiments; Michał Strankowski and Piotr Korzeniewski analyzed the data and prepared the paper; Sabu Thomas supervised the work.

Conflicts of Interest: The authors declare no conflict of interest.

\section{References}

1. Novoselov, K.S.; Geim, A.K.; Morozov, S.V.; Jiang, D.; Katsnelson, M.I.; Grigorieva, I.V.; Dubonos, S.V.; Firsov, A.A. Two-dimensional gas of massless Dirac fermions in graphene. Nature 2005, 438, 197-200. [CrossRef] [PubMed]

2. Novoselov, K.S.; Geim, A.K.; Morozov, S.V.; Jiang, D.; Zhang, Y.; Dubonos, S.V.; Grigorieva, I.V.; Firsov, A.A. Electric field effect in atomically thin carbon films. Science 2004, 306, 666-669. [CrossRef] [PubMed] 
3. Castro Neto, A.H.; Peres, N.M.R.; Novoselov, K.S.; Geim, A.K.; Guinea, F. The electronic properties of graphene. Rev. Mod. Phys. 2009, 81, 109-162. [CrossRef]

4. Zhu, Y.; James, D.K.; Tour, J.M. New routes to graphene, graphene oxide and their related applications. Adv. Mater. 2012, 24, 4924-4955. [CrossRef] [PubMed]

5. Pei, S.; Cheng, H.-M. The reduction of graphene oxide. Carbon 2012, 50, 3210-3228. [CrossRef]

6. Berger, C.; Song, Z.; Li, X.; Wu, X.; Brown, N.; Naud, C.; Mayou, D.; Li, T.; Hass, J.; Marchenkov, A.N.; et al. Electronic Confinement and Coherence in Patterned Epitaxial Graphene. Science 2006, 312, 1191-1196. [CrossRef] [PubMed]

7. Instytut Technologii Materiałów Elektronicznych. Available online: http://www.itme.edu.pl/ (accessed on 29 December 2017).

8. Li, X.; Zhu, H.; Wang, K.; Cao, A.; Wei, J.; Li, C.; Jia, Y.; Li, Z.; Li, X.; Wu, D. Graphene-on-silicon schottky junction solar cells. Adv. Mater. 2010, 22, 2743-2748. [CrossRef] [PubMed]

9. Schwierz, F. Graphene transistors. Nat. Nanotechnol. 2010, 5, 487-496. [CrossRef] [PubMed]

10. Bian, J.; Lin, H.L.; He, F.X.; Wei, X.W.; Chang, I.T.; Sancaktar, E. Fabrication of microwave exfoliated graphite oxide reinforced thermoplastic polyurethane nanocomposites: Effects of filler on morphology, mechanical, thermal and conductive properties. Compos. Part A Appl. Sci. Manuf. 2013, 47, 72-82. [CrossRef]

11. Strankowski, M.; Piszczyk, Ł.; Kosmela, P.; Korzeniewski, P. Morphology and the physical and thermal properties of thermoplastic polyurethane reinforced with thermally reduced graphene oxide. Pol. J. Chem. Technol. 2015, 17, 88-94. [CrossRef]

12. Canales, J.; Muñoz, M.E.; Fernández, M.; Santamaría, A. Rheology, electrical conductivity and crystallinity of a polyurethane/graphene composite: Implications for its use as a hot-melt adhesive. Compos. Part A Appl. Sci. Manuf. 2016, 84, 9-16. [CrossRef]

13. Cai, D.; Jin, J.; Yusoh, K.; Rafiq, R.; Song, M. High performance polyurethane/functionalized graphene nanocomposites with improved mechanical and thermal properties. Compos. Sci. Technol. 2012, 72, 702-707. [CrossRef]

14. Pokharel, P.; Choi, S.; Lee, D.S. The effect of hard segment length on the thermal and mechanical properties of polyurethane/graphene oxide nanocomposites. Compos. Part A Appl. Sci. Manuf. 2015, 69, 168-177. [CrossRef]

15. Park, J.H.; Kim, B.K. Infrared light actuated shape memory effects in crystalline polyurethane/graphene chemical hybrids. Smart Mater. Struct. 2014, 23, 025038. [CrossRef]

16. Nguyen, D.A.; Lee, Y.R.; Raghu, A.V.; Jeong, H.M.; Shin, C.M.; Kim, B.K. Morphological and physical properties of a thermoplastic polyurethane reinforced with functionalized graphene sheet. Polym. Int. 2009, 58, 412-417. [CrossRef]

17. Nawaz, K.; Khan, U.; Ul-Haq, N.; May, P. Observation of mechanical percolation in functionalized graphene oxide/elastomer composites. Carbon 2012, 50, 4489-4494. [CrossRef]

18. Liao, K.H.; Park, Y.T.; Abdala, A.; Macosko, C. Aqueous reduced graphene/thermoplastic polyurethane nanocomposites. Polymer 2013, 54, 4555-4559. [CrossRef]

19. Kim, H.; Miura, Y.; Macosko, C.W. Graphene/Polyurethane Nanocomposites for Improved Gas Barrier and Electrical Conductivity. Chem. Mater. 2010, 22, 3441-3450. [CrossRef]

20. Kim, J.T.; Kim, B.K.; Kim, E.Y.; Kwon, S.H.; Jeong, H.M. Synthesis and properties of near IR induced self-healable polyurethane/graphene nanocomposites. Eur. Polym. J. 2013, 49, 3889-3896. [CrossRef]

21. Han, S.; Chun, B.C. Preparation of polyurethane nanocomposites via covalent incorporation of functionalized graphene and its shape memory effect. Compos. Part A Appl. Sci. Manuf. 2014, 58, 65-72. [CrossRef]

22. Khan, U.; May, P.; O'Neill, A.; Coleman, J.N. Development of stiff, strong, yet tough composites by the addition of solvent exfoliated graphene to polyurethane. Carbon 2010, 48, 4035-4041. [CrossRef]

23. Choi, J.T.; Kim, D.H.; Ryu, K.S.; Lee, H.; Jeong, H.M.; Shin, C.M.; Kim, J.H.; Kim, B.K. Functionalized graphene sheet/polyurethane nanocomposites: Effect of particle size on physical properties. Macromol. Res. 2011, 19, 809-814. [CrossRef]

24. Ponnamma, D.; Sadasivuni, K.K.; Strankowski, M.; Moldenaers, P.; Thomas, S.; Grohens, Y. Interrelated shape memory and Payne effect in polyurethane/graphene oxide nanocomposites. RSC Adv. 2013, 3, 16068-16079. [CrossRef]

25. Choi, J.T.; Dao, T.D.; Oh, K.M.; Lee, H.; Jeong, H.M.; Kim, B.K. Shape memory polyurethane nanocomposites with functionalized graphene. Smart Mater. Struct. 2012, 21, 075017. [CrossRef] 
26. Oh, S.M.; Oh, K.M.; Dao, T.D.; Lee, H.I.; Jeong, H.M.; Kim, B.K. The modification of graphene with alcohols and its use in shape memory polyurethane composites. Polym. Int. 2013, 62, 54-63. [CrossRef]

27. Lorenzetti, A.; Roso, M.; Bruschetta, A.; Boaretti, C.; Modesti, M. Polyurethane-graphene nanocomposite foams with enhanced thermal insulating properties. Polym. Adv. Technol. 2016, 27, 303-307. [CrossRef]

28. Kumar, M.; Chung, J.S.; Kong, B.S.; Kim, E.J.; Hur, S.H. Synthesis of graphene-polyurethane nanocomposite using highly functionalized graphene oxide as pseudo-crosslinker. Mater. Lett. 2013, 106, 319-321. [CrossRef]

29. Kim, J.T.; Kim, B.K.; Kim, E.Y.; Park, H.C.; Jeong, H.M. Synthesis and shape memory performance of polyurethane/graphene nanocomposites. React. Funct. Polym. 2014, 74, 16-21. [CrossRef]

30. Liang, J.; Xu, Y.; Huang, Y.; Zhang, L.; Wang, Y.; Ma, Y.; Li, F.; Guo, T.; Chen, Y. Infrared-Triggered Actuators from Graphene-Based Nanocomposites. J. Phys. Chem. C 2009, 113, 9921-9927. [CrossRef]

31. Feng, Y.; Qin, M.; Guo, H.; Yoshino, K.; Feng, W. Infrared-actuated recovery of polyurethane filled by reduced graphene oxide/carbon nanotube hybrids with high energy density. ACS Appl. Mater. Interfaces 2013, 5, 10882-10888. [CrossRef] [PubMed]

32. Wang, X.; Hu, Y.; Song, L.; Yang, H.; Xing, W.; Lu, H. In situ polymerization of graphene nanosheets and polyurethane with enhanced mechanical and thermal properties. J. Mater. Chem. 2011, 21, 4222. [CrossRef]

33. Wang, T.; Zhao, L.; Shen, J.; Wu, L.; Van der Bruggen, B. Enhanced Performance of Polyurethane Hybrid Membranes for $\mathrm{CO}_{2}$ Separation by Incorporating Graphene Oxide: The Relationship between Membrane Performance and Morphology of Graphene Oxide. Environ. Sci. Technol. 2015, 49, 8004-8011. [CrossRef] [PubMed]

34. Yao, H.B.; Ge, J.; Wang, C.F.; Wang, X.; Hu, W.; Zheng, Z.J.; Ni, Y.; Yu, S.H. A flexible and highly pressure-sensitive graphene-polyurethane sponge based on fractured microstructure design. Adv. Mater. 2013, 25, 6692-6698. [CrossRef] [PubMed]

35. Tung, T.T.; Robert, C.; Castro, M.; Feller, J.F.; Kim, T.Y.; Suh, K.S. Enhancing the sensitivity of graphene/ polyurethane nanocomposite flexible piezo-resistive pressure sensors with magnetite nano-spacers. Carbon 2016, 108, 450-460. [CrossRef]

36. Muralidharan, M.N.; Ansari, S. Thermally reduced graphene oxide/thermoplastic polyurethane nanocomposites as photomechanical actuators. Adv. Mater. Lett. 2013, 4, 927-932. [CrossRef]

37. Li, J.; Zhang, G.; Deng, L.; Zhao, S.; Gao, Y.; Jiang, K.; Sun, R.; Wong, C. In situ polymerization of mechanically reinforced, thermally healable graphene oxide/polyurethane composites based on Diels-Alder chemistry. J. Mater. Chem. A 2014, 2, 20642-20649. [CrossRef]

38. Huang, L.; Yi, N.; Wu, Y.; Zhang, Y.; Zhang, Q.; Huang, Y.; Ma, Y.; Chen, Y. Multichannel and repeatable self-healing of mechanical enhanced graphene-thermoplastic polyurethane composites. Adv. Mater. 2013, 25, 2224-2228. [CrossRef] [PubMed]

39. Khudyakov, I.V.; Zopf, D.R.; Turro, N.J. Polyurethane Nanocomposites. Des. Monomers Polym. 2009, 12, 279-290. [CrossRef]

40. Ponnamma, D.; Sadasivuni, K.K.; Grohens, Y.; Guo, Q.; Thomas, S. Carbon nanotube based elastomer composites-An approach towards multifunctional materials. J. Mater. Chem. C 2014, 2, 8446-8485. [CrossRef]

41. Yaragalla, S.; Meera, A.P.; Kalarikkal, N.; Thomas, S. Chemistry associated with natural rubber-graphene nanocomposites and its effect on physical and structural properties. Ind. Crops Prod. 2015, 74, 792-802. [CrossRef]

42. Bhattacharya, M. Polymer nanocomposites-A comparison between carbon nanotubes, graphene, and clay as nanofillers. Materials (Basel) 2016, 9, 1-35. [CrossRef] [PubMed]

43. Bera, M.; Maji, P.K. Effect of structural disparity of graphene-based materials on thermo-mechanical and surface properties of thermoplastic polyurethane nanocomposites. Polymer 2017, 119, 118-133. [CrossRef]

44. Yadav, S.K.; Cho, J.W. Functionalized graphene nanoplatelets for enhanced mechanical and thermal properties of polyurethane nanocomposites. Appl. Surf. Sci. 2013, 266, 360-367. [CrossRef]

45. Cruz, S.M.; Viana, J.C. Structure-Properties Relationships in Thermoplastic Polyurethane Elastomer Nanocomposites: Interactions between Polymer Phases and Nanofillers. Macromol. Mater. Eng. 2015, 300, 1153-1162. [CrossRef]

46. Barick, A.K.; Tripathy, D.K. Effect of organically modified layered silicate nanoclay on the dynamic viscoelastic properties of thermoplastic polyurethane nanocomposites. Appl. Clay Sci. 2011, 52, 312-321. [CrossRef] 
47. Strankowski, M.; Strankowska, J.; Gazda, M.; Piszczyk, Ł.; Nowaczyk, G.; Jurga, S. Thermoplastic polyurethane/(organically modified montmorillonite) nanocomposites produced by in situ polymerization. Express Polym. Lett. 2012, 6, 610-619. [CrossRef]

48. Kwon, J.; Kim, H. Comparison of the properties of waterborne polyurethane/multiwalled carbon nanotube and acid-treated multiwalled carbon nanotube composites prepared by in situ polymerization. J. Polym. Sci. Part A Polym. Chem. 2005, 43, 3973-3985. [CrossRef]

49. Xia, H.; Song, M. Preparation and characterization of polyurethane-carbon nanotube composites. Soft Matter 2005, 1, 386. [CrossRef]

50. Benedito, A.; Buezas, I.; Gimenez, E.; Galindo, B.; Ortega, A. Dispersion and Characterization of Thermoplastic Polyurethane/Multiwalled Carbon Nanotubes by Melt Mixing. J. Appl. Polym. Sci. 2011, 122, 3744-3750. [CrossRef]

51. Quan, H.; Zhang, B.; Zhao, Q.; Yuen, R.K.K.; Li, R.K.Y. Facile preparation and thermal degradation studies of graphite nanoplatelets (GNPs) filled thermoplastic polyurethane (TPU) nanocomposites. Compos. Part A 2009, 40, 1506-1513. [CrossRef]

52. Pokharel, P.; Lee, D.S. High performance polyurethane nanocomposite films prepared from a masterbatch of graphene oxide in polyether polyol. Chem. Eng. J. 2014, 253, 356-365. [CrossRef]

53. Bagdi, K.; Molnar, K.; Sajo, I.; Pukanszky, B. Specific interactions, structure and properties in segmented polyurethane elastomers. Express Polym. Lett. 2011, 5, 417-427. [CrossRef]

54. Marcano, D.C.; Kosynkin, D.V.; Berlin, J.M.; Sinitskii, A.; Sun, Z.; Slesarev, A.; Alemany, L.B.; Lu, W.; Tour, J.M. Improved synthesis of graphene oxide. ACS Nano 2010, 4, 4806-4814. [CrossRef] [PubMed]

55. Strankowski, M.; Włodarczyk, D.; Piszczyk, Ł.; Strankowska, J. Polyurethane Nanocomposites Containing Reduced Graphene Oxide, FTIR, Raman, and XRD Studies. J. Spectrosc. 2016, 2016, 7520741. [CrossRef]

56. Urban, M.; Strankowski, M. Shape Memory Polyurethane Materials Containing Ferromagnetic Iron Oxide and Graphene Nanoplatelets. Materials 2017, 10, 1-23. [CrossRef] [PubMed]

57. Piszczyk, Ł.; Kosmela, P.; Strankowski, M. Elastic polyurethane foams containing graphene nanoplatelets. Adv. Polym. Technol. 2017, 1-10. [CrossRef]

58. Kucińska-Lipka, J.; Gubańska, I.; Strankowski, M.; Cieśliński, H.; Filipowicz, N.; Janik, H. Synthesis and characterization of cycloaliphatic hydrophilic polyurethanes, modified with L-ascorbic acid, as materials for soft tissue regeneration. Mater. Sci. Eng. C 2017, 75, 671-681. [CrossRef] [PubMed]

59. Potts, J.R.; Dreyer, D.R.; Bielawski, C.W.; Ruoff, R.S. Graphene-based polymer nanocomposites. Polymer 2011, 52, 5-25. [CrossRef]

60. Mittal, V. Functional Polymer Nanocomposites with Graphene: A Review. Macromol. Mater. Eng. 2014, 299, 906-931. [CrossRef]

61. Mai, Y.W.; Yu, Z.Z. Polymer Nanocomposites; Woodhead Publishing Limited: Sawston, UK, 2006; ISBN 978-1-85573-969-7.

62. Du, N.; Zhao, C.; Chen, Q.; Wu, G.; Lu, R. Preparation and characterization of nylon 6/graphite composite. Mater. Chem. Phys. 2010, 120, 167-171. [CrossRef]

63. Chatterjee, K.; Naskar, K. Study on Characterization and Properties of Nanosilica-Filled Thermoplastic Vulcanizates. Polym. Eng. Sci. 2008, 48, 1077-1084. [CrossRef]

64. Bokobza, L. Multiwall carbon nanotube-filled natural rubber: Electrical and mechanical properties. Express Polym. Lett. 2012, 6, 213-223. [CrossRef]

65. Quan, Y.; Lu, M.; Tian, M.; Yan, S.; Yu, Z.; Zhang, L. Functional and mechanical properties of acrylate elastomer/expanded graphite nanocomposites. J. Appl. Polym. Sci. 2013, 130, 680-686. [CrossRef]

66. Leblanc, J.L. Nonlinear viscoelastic properties of molten thermoplastic vulcanisates: An insight on their morphology. J. Appl. Polym. Sci. 2006, 101, 4193-4205. [CrossRef]

67. Li, X.; Deng, H.; Li, Z.; Xiu, H.; Qi, X.; Zhang, Q.; Wang, K.; Chen, F.; Fu, Q. Graphene/thermoplastic polyurethane nanocomposites: Surface modification of graphene through oxidation, polyvinyl pyrrolidone coating and reduction. Compos. Part A Appl. Sci. Manuf. 2015, 68, 264-275. [CrossRef]

(C) 2018 by the authors. Licensee MDPI, Basel, Switzerland. This article is an open access article distributed under the terms and conditions of the Creative Commons Attribution (CC BY) license (http:/ / creativecommons.org/licenses/by/4.0/). 